\title{
VÁROSJÁRÓ JOGÁSZKÉPZÉS \\ A DEBRECENI JOGI OKTATÁS HELYSZÍNEINEK ALAKULÁSA, KÜLÖNÖS TEKINTETTEL A MAI KASSAI ÚTI CAMPUS TÖRTÉNETÉRE
}

\begin{abstract}
Moving LeGal EDUCATION - The EVOLUTION OF Locality of tHe LeGal EDUCATION IN DEBRECEN With SPECIAL REGARD TO THE HISTORY OF CAMPUS KASSAI. The legal education in Debrecen has a long history. It started in the Reformed Collage of Debrecen in the middle of the $18^{\text {th }}$ century. As a state university, it was established by the Act XXXVI of 1912. Until the main building of the University of Debrecen was completed (1932) the Faculty of Law had been operating in many places in the city. First, in the building of Reformed Collage, but some legal departments were in an apartment house on the main street. After 1932, the faculty of law had suitable offices in the main building of the University. Between 1949 and 1996 the legal education was suspended, and its offices were occupied by other departments. In the year of 1996 a solution had to be found, the restarted legal education needed new buildings. The new place was found on the field of ex-soviet barrack on the Kassai Street. This site was a cavalry barrack before the WWII. Some of the original buildings can still be found today, and many new buildings were built in the last couple of years e. g. library, student hostel, educational buildings.

The faculty of law has also found its place on this campus. Its last moving was in the year of 2015, and it has a nice old-style group of buildings now.
\end{abstract}

\section{Bevezetö gondolatok}

A Debreceni Egyetem Állam- és Jogtudományi Kara a 2017/2018-as tanévben ünnepli a debreceni jogi oktatás újraindulásának 21. évfordulóját. E tanulmánynak az apropója azonban néhány évvel korábbra nyúlik vissza: a 2011/2012-es tanévre. Ekkor a kar többszörösen jubilált, ugyanis 2011-ben ünnepelte újraalapításának 15., s 2012-ben - mint a Debreceni Egyetem, az egykori Debreceni magyar királyi Tudományegyetem alapító kara - az alapítás százéves évfordulóját. Ez az alkalom már akkor lehetőséget nyújtott az elmúlt évszázad, sőt a jogelőd intézmények (elsősorban a Református Kollégium) több évszázadot átfogó történetének ismételt feldolgozására. ${ }^{1}$

${ }^{1}$ A szerző azonos című tanulmányával 2012-ben a Debreceni Egyetem Állam- és Jogtudományi Kara által az egyetem alapításának 100 éves évfordulójára meghirdetett Centenáriumi pályázaton az oktatói tagozatban első helyezést nyert. A tanulmány Kassai úti laktanyára vonatkozó része később meg is jelent. Vö. Megreri-Pálffi Zoltán, Kaszárnyától a Campusig = Interdiszciplinaritás a régiókutatásban III., szerk. Bartha Ákos, SzÁlKai Tamás, Debrecen, 2013, 93-117. 
A közelmúltban és e jubileumi esztendőkben számos hiánypótló tanulmány, önálló kötet látott napvilágot, amely a jogi oktatás debreceni megjelenését és annak fejlődését tárgyalta, ezért jelen feldolgozás nem erre kívánja a hangsúlyt fektetni, hanem a jogi oktatásnak keretet adó, azt befogadó falak „megfestésére” vállalkozik.

Az egyetemi élet elválaszthatatlan annak helyszínétől, legyen a részese akár hallgató, akár oktató. Az ember nap mint nap találkozik az oktatást és tanulást befogadó térrel, épületekkel. Óhatatlanul hangulatok, élmények, érzések, érzelmek kapcsolódnak az évek során e falakhoz, amelyek némán szemlélik e sorsokat.

Talán kíváncsiak vagyunk arra, hogy e falak kiket láttak és kiket szolgáltak korábban. Miért állnak itt, és miért olyanok, amilyenek. E kérdésekre megtalálható a válasz a múlt feltárása, a hely szellemének megidézése révén.

E dolgozat ennek ered nyomába, $s$ a debreceni jogi oktatás alakulásának rövid áttekintése mellett a mai campus területének történetét tárja fel.

\section{A debreceni jogi oktatás $-A$ kezdetek és a jogászoktatás megszilárdulása}

A debreceni jogi oktatás kezdetei a 18. század közepére tehetők. A Református Kollégium filozófia tanszékének bölcseleti előadásai körében kezdődött elsőként a természetjog és a nemzetközi jog oktatása, majd Maróthi György római jogi ismereteket is továbbadott diákjainak. ${ }^{2}$ A kollégium 1796. október 10-i közgyülésén elhatározta, hogy hazai törvényeket fog oktatni diákjai számára. E feladat ellátására meghívta Széplaki Pál losonci ügyvédet, aki csak a második invitálásra tett eleget a felkérésnek, s 1800. március 30-án tartotta meg székfoglaló beszédét. ${ }^{3}$ Mégis még több évtizedet kellett várni ahhoz, hogy a debreceni jogi oktatás meggyökeresedjen. ${ }^{4}$ A neoabszolutizmus első éveiben rendkívüli erőfeszítéseket tett a kollégium a jogi fakultás fenntartására. ${ }^{5}$ A sikerek

${ }^{2}$ Vö. Balogh Ferenc, A debreceni jogakadémia keletkezése, fejlödése és a jogászifjúság, Debrecen, 1905, 3.; То́тн Béla, Maróthi György történelemtanitása és régiségtani elöadásai = A Debreceni Déri Múzeum Évkönyve, 1980, Debrecen, 1982, 457.; Hollósi Gábor, A debreceni Jog-és Államtudományi Kar története (1914-1949), Debrecen, 2007, 13.; Mezey Barna, A jogakadémiák a jogászképzés történetében = A Pécsi Püspöki Joglyceum emlékezete 1833-1923, szerk. KajTár István, PoHÁNKa Éva, Pécs, 2009, 19.; P. Szabó Béla, Tanulságos évtizedek: A Debreceni Tudományegyetem Jog-és Államtudományi Kara (1914-1949), Debrecen, 2011, 7.

3 P. SzABó, i. m., 7 .

${ }^{4}$ Az 1810-es években alapítványok segítették immár nemcsak Széplaki professzor javadalmazását, hanem a hallgatók segélyezését és a könyvállomány gyarapítását is, $s$ majd csak a szabadságharcot követően lett két jogtanára a kollégiumnak. Vö. BaLoGH, i. m., 8-13.; P. SzABó, i. m., 8.

5 1850-ben a jogakadémiákat államilag átszervezték, s e változásokat a kollégium is kénytelen volt követni ragaszkodván a jogoktatáshoz. Az erőfeszítéseknek és a közadakozásnak köszönhetően 1853 novemberében elismerték a debreceni jogakadémiát. Vö. Csohány János, $A$ korszakváltások évszázada = A Debreceni Református Kollégium története, szerk. BarCza József, Budapest, 1988, 194; P. Szabó, i. m., 8. 
ellenére a kormányzat által támasztott újabb feltételek miatt 1856-ban kénytelen volt a kollégium a jogi oktatást a Teológiai Kar keretei között megszervezni. ${ }^{6}$

A jogakadémia 1861-ben indulhatott újra, azonban a Helytartótanács szabta feltételeket csak az 1864/1865-ös tanévtől tudták teljesíteni, s 1874-ig mondhatni zavartalanul folyt a jogi oktatás a városban. ${ }^{7}$ Az 1874-es jogakadémiai reform ismét változásokat követelt, $s$ az ekkor támasztott követelmények teljesítéséhez ismét hosszú évekre volt szüksége mind a városnak, mind a kollégiumnak. ${ }^{8}$

Az 1890-es évektől a debreceni jogakadémia már beilleszkedett az ország többi hasonló intézménye közé, sőt az elsők között tartották számon. ${ }^{9}$ Az egyetemi szintủ jogi oktatás azonban csak a Debreceni Magyar Királyi Tudományegyetem 1912-es megalapításával, illetve 1914-es indulásával kezdődhetett meg Debrecen városában.

\section{A jogászképzés helyei a városban}

Természetes, hogy a kollégium kebelében meginduló jogi oktatás helyét ezen intézmény falai között találta meg. A kezdetektől az egyetemi oktatás megindulásáig a kollégium épülete adott otthont a joghallgatóknak és professzoraiknak.

E helyről szemléletesen szól Balogh Ferenc 1905-ös munkájában: „Az a régi épület, melyben ünnepelték a jogtudományok megszólalását föiskolánkban, eltünt az 1802-iki tüzvész alatt s a mai homloképület, mely a nagytemplomra néz, állott helyébe. A régi egyemeletes kollégium elsö emeletének közepén volt a nagyterem (auditorium magnum) századok alatt a legfontosabb iskolai ünnepségeknek volt az néma tanúja, itt folyt le Széplaki beiktatása is. A nyári félévben történt a beiktatás, szabályos pályáját 1800-1801-dik tanévvel kezdte meg a jogi szak, amikor a pályavégzettek is (az öreg deákok), akik 31-en valának, hallgatták rendkivülileg a jogi órákat. Az akadémia hat évének hallgatói akkor 487-en voltak, mert a mai gymnasium VII. és VIII. osztálya is 1. és 2. évi bölcsészekként az akadémiához tartozott." 10

Valóban, sokak által ismert tény, hogy a Református Kollégium is áldozatául esett a Debrecenben nem ritkán vendégeskedő tüzeknek, s 1802-ben a Nagytemplom felé néző szárnya leégett. Ahogy Nagy Sándor írta 1933-ban e gyakori tűzesetek kapcsán: „... fel kell tennünk, hogy az iskola épülete ez okból is igen gyakran változtatta ábrázatát”. ${ }^{11}$

Az 1802-es tűzvész előtt a kollégium már valóságos iskola képét mutatta. (1. kép) „A hagyomány szerint a négyszög alakúvá formálódott zárt udvarú Kollégiumnak a nyu-

\footnotetext{
${ }^{6}$ Vö. NaGY Sándor, A Debreceni Kollégium mint egységes intézmény az egyetem kiválásáig, Debrecen, 1940, 249-250; P. Szabó, i. m., 8.

7 Vö. Balogh, i. m., 15; Hollósi, i. m., 16; P. Szabó, i. m., 8.

${ }^{8}$ Vö. Hollósı, i. m., 16-17; P. Szabó, i. m., 9.

9 Vö. P. Szabó, i. m., 9., a tanszékekről lásd: NAGY Sándor, i. m., 1940, 254-258.

${ }^{10}$ BaLogh, i.m., 5.

${ }^{11}$ Nagy Sándor, A Debreceni Református Kollégium, Hajdúhadház, 1933, 328.
} 
gati szárny volt a legrégibb része."12 Főhomlokzata dél felé nézett, $s$ délnyugati sarkán kaputornyon át vezetett be az út a belsőbe. E torony egy, a tanórák kezdetét és végét jelző csengőnek, és egy I. Rákóczi György által adományozott harangnak adott otthont, amely a haláleseteket és a kitiltásokat jelezte, illetve veszélyre hívta fel a figyelmet. A déli szárny a kis és nagy auditórium, valamint hat osztályterem helye volt. A többi szárnyban a diáktisztviselők és diákok szobái voltak találhatók. A hátsó udvaron a magtár és a tüzoltó diákok szertára állt. ${ }^{13}$ "A gyakori tüzkárok, a lakosság anyagi erejét felemésztö sarcolások, hadi események, "mikor a mindenfelé való adom "volt a fennmaradás záloga, kizárják annak lehetöségét, hogy az ó épületet fényes késö reneszánsz épitménynek képzeljük. Minden bizonnyal puritán hajlék volt, egyes jelek azonban arra vallanak, hogy - mint az András-templom, az Alföld legjelentékenyebb gótikus temploma esetében - a kollégium fenntartói magasabb célokra is áldoztak: a nagy auditorium falát pl. freskók diszitették. "14 A kilenc falfestmény egyike Justitia allegorikus alakját ábrázolta. ${ }^{15}$

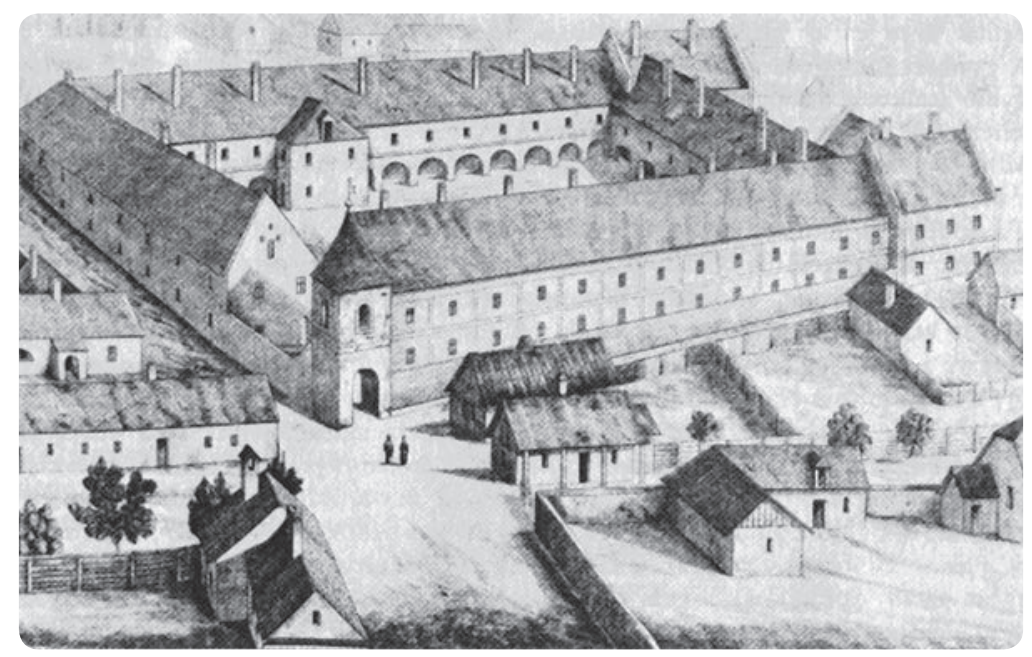

1. kép. Kallós Kálmán „A Debreczeni Ref. Föiskola Ó épülete s környezete az 1802-ki tüz elött Madár távlatból" c. rajza. ${ }^{16}$

Ez a 17. század derekán emelt épület egyre növekvő számú diákot fogadott be. Míg a 16. század végén 100-200 togatus deákja és kb. 800 tanulója volt a kollégiumnak, addig a következő évtizedekben ez a létszám a többszörösére emelkedett. A 18. század közepétől már 2000 körül volt az akadémiai és alsó tagozat összlétszáma. Az alsó tago-

${ }^{12}$ G. Szabó Botond, $A$ Kollégium épületeinek története = A Debreceni Református Kollégium története, i. m., 354 .

${ }^{13}$ Vö. NAGY Sándor, i. m., 1933, 329.

14 G. Szabó, i. m., 355.

15 Uo., 361.

${ }^{16}$ A rajzot közli: G. SzABó, i. m., 356. 
zatosok zöme helybeli volt, így elhelyezésük nem adott feladatot, s azok az akadémiai tagozatosak, akik nem voltak togatus hallgatók, mint a jogászok, az 1792. évi törvény tiltása miatt nem lakhattak a kollégiumban. ${ }^{17}$ Annak ellenére, hogy a városban nagy számban laktak diákok, a kollégiumban élők szűkösen fértek el, emellett a déli szárny már javításra szorult. E körülmények miatt 1801-ben megszületett az elhatározás, hogy a déli szárnyat el kell bontani, $s$ helyébe egy új, háromemeletes épületet kell építeni. Az egyházkerületi közgyűlés az építőanyag előteremtésére gyűjtést indított. 1802 elején a terveket is elkészíttették. Azonban az előkészületek húzódtak, ezért az építést a következö évre halasztották. „Az isteni gondviselés nyilatkozott meg e határozatban. Ha az épitkezés megindul, s az épitési anyag összehalmozódik, végzetes szerencsétlenség éri a Kollégiumot azzal a tüzesettel, mely ugyanazon évben a városon végigpusztított és amelyben a Kollégium is leégett." 18 A tűzvész tehát csak elkezdte azt, amit már elterveztek. A déli szárny bontása 1803. február 7-én indult meg az épület középső szakaszán, így a két szélső auditóriumot még egy ideig használhatták tanításra. ${ }^{19}$ Az épület terveit Péchy Mihály készítette el. Összesen hat változat készült, amelyből végül a III. tervet fogadták el, egy kétemeletes, két oldalrizalitos fóhomlokzattal. ${ }^{20}$ (2. kép)

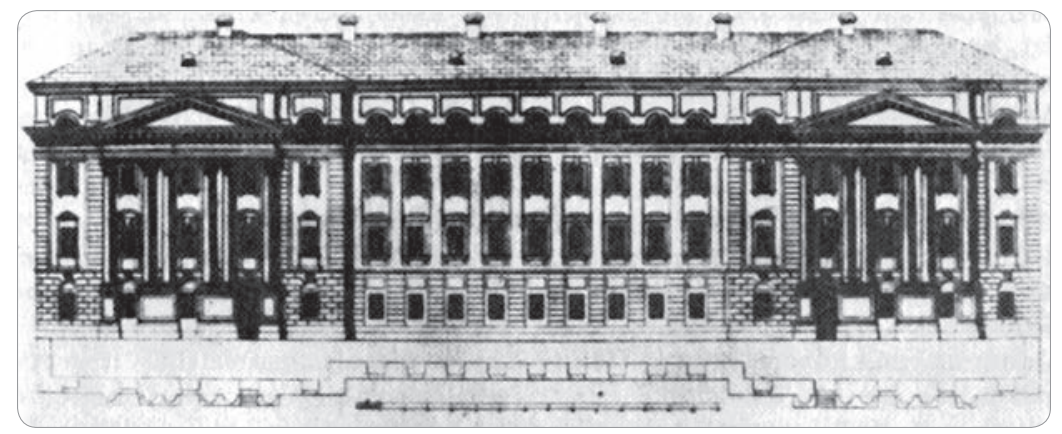

2. kép. A kollégium déli homlokzata, Péchy Mihály terve. ${ }^{21}$

Bár a homlokzaton olvasható felirat 1803 és 1816 közötti építésről szól, mind a külső, de leginkább a belső befejezés elhúzódott még a következő évekre. ${ }^{22}$

A megmaradt régi épületszárnyak eltörpültek az új déli épület mögött, $s$ az idő vasfoga sem kímélte őket, mégis évtizedek kellettek ahhoz, hogy a kollégium ma is ismert formája megvalósuljon. Az 1860-as évek derekán lendült előre az oldalsó szárnyak építésének ügye, mígnem 1875 januárjára elkészült a három új épületszárny. ${ }^{23}$

17 Uo, 361.

${ }^{18}$ NAGy Sándor, i. m., 1933, 330.

19 G. Szabó, i. m., 375.

${ }^{20}$ Uo.

${ }^{21}$ A képet közli: G. Szabó, i. m., 379.

22 Vö. G. Szabó, i. m., 378-379.

${ }^{23}$ Uo., 382-383; Nagy Sándor 1873-as évet jelöli meg az átadás idejeként. (Vö. NAGY Sándor, i. m., 1933, 335.) 
Ebből az épületből indult útjára a Debreceni Magyar Királyi Tudományegyetem, s kebelében a jogi kar, miután az 1912. évi XXXVI. törvénycikk a pozsonyi mellett felállította a debreceni tudományegyetemet is. Az oktatás azonban csak az 1914-es esztendővel kezdődött meg.

Az egyetemi oktatás megindulásának nehézségei a helyhiányban is megmutatkoztak. Ez természetesen a jogi képzést is érintette ugyanúgy, mint a többi kart.

Az oktatás a jogelőd intézmény épületében, a kollégium helyiségeiben vette kezdetét. A helyiséghasználatról a város, a kollégium és a Debreceni Református Egyház küldöttsége állapodott meg az illetékes miniszterrel. „Az egyetem használatára bocsátott kollégiumi helyiségekröl 1914 májusában Szentpéteri Kun Béla akadémiai igazgató és Tóth Lajos miniszteri tanácsos döntöttek. [...] A kialakult háborús viszonyok azonban az elsö helyiségfelosztást is felülírták, hiszen a katonaság 1914 nyarán a Kollégium épületének jelentös részét tartalékkórház céljaira lefoglalta, és csak 1916 végén adta vissza (az egyetem a szükséges fertötlenitö munkálatok befejezte után, csak 1917 elején vehette birtokba). "24 A helyiséggondok mind az oktatókat, mind a hallgatókat érintették, ugyanis az előadó és a szemináriumi termek egyaránt hiányoztak. A jogi kar részére a kollégiumban tizenegy (három felosztásával összesen tizennégy) helyiséget adtak át, $s$ a jogi vizsgálatok helyszínéül a kistanácstermet használták. ${ }^{25} \mathrm{~A}$ jogászképzés szempontjából megoldást jelentett, hogy a kiköltöző Református Gimnázium hat tantermét megkapták, továbbá 1915 őszén, Bernolák Nándor rektor saját kockázatára az akkori Ferenc József, ma Piac utca 51. szám alatti, ún. Csanak-házban (3. kép) tizenkét helyiségből álló lakást bérelt a jogi kar és a bölcsészeti kar egyes tanszékei számára. ${ }^{26}$

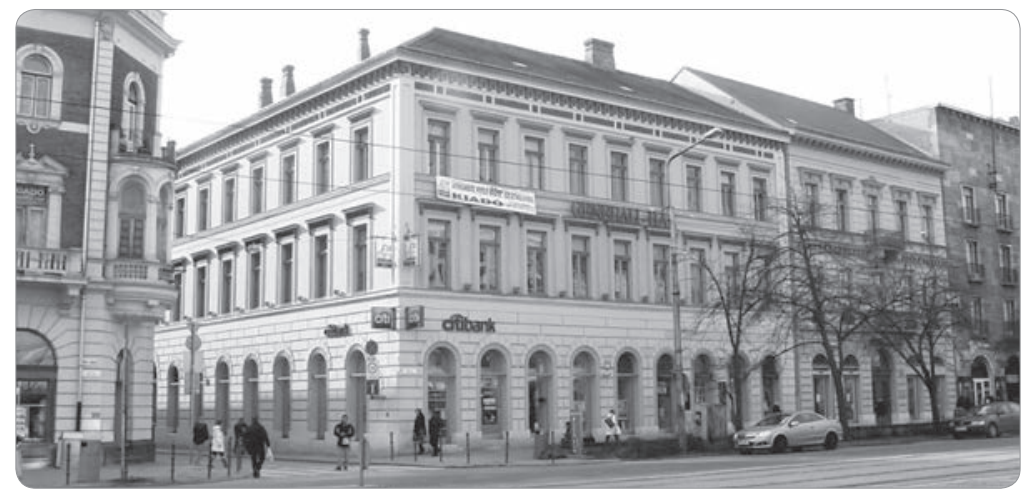

3. kép. Debrecen, Piac utca 51. szám, az ún. Csanak-ház, amely 1874-ben épült Csanak József füszerkereskedö számára. ${ }^{27}$

${ }^{24}$ Mudrák József, KiráLy Sándor, Felépités, müködés, oktatás, tudományos munka = A Debreceni Egyetem története, főszerk. Orosz István, szerk. ifj. Barta János, Debrecen, 2012, 57.

${ }^{25}$ Vö. P. SZABó, i. m., 11-12.

${ }^{26}$ Vö. Soós Ildikó, P. Szabó Béla, Bernolák Nándor. Büntetöjogász - népjóléti-miniszter-ügyvéd = A Debreceni Tudományegyetem jogász rektorai (1915-1947), szerk. P. SzaBó Béla, MaDAI Sándor, Debrecen, 2002, 17; P. Szabó, i. m., 14; Mudrák, Király, i. m., 58.

27 S. VARGa Pál, Tóth Pál, Debrecen, Debrecen, 1993, 54. A fényképet a szerző készítette 2012 márciusában. 
A végleges megoldás a Nagyerdőben elhelyezett Foópület elkészültével született meg, amelynek munkálatai már az 1920-as években megkezdődtek. Az épület valamennyi kar számára fontos, közösen elérendő cél volt. Természetesen a jogi kar is kivette a részét az előkészületek terén a feladatokból. Említésre méltó, hogy a jogász Illyefalvi Vitéz Géza rektorsága alatt, 1927. június 3-án, Horthy Miklós jelenlétében történt meg az alapkőletétel. ${ }^{28}$

A Foópület 1932. május 15-i megnyitását követően valamennyi alapító kar méltó környezetben folytathatta munkáját. (4. kép) A jogi kar a második emeleti helyiségeket vehette birtokba. Hollósi Gábor 2007-ben kiadott, a jogi kar történetét feldolgozó munkájából kiderül, hogy az egyes jogi kari tanszékek, szemináriumok mely helyiségekben müködtek. ${ }^{29}$

A második világháború alatt a német csapatok a diákszállások elfoglalása után, 1944. május 30-án bejelentették igényüket a Fóépületre vagy a tanári villákra, s a rektor döntése nyomán az előbbit foglalták el..$^{30}$

A háborút követően lassan újjászerveződött az oktatás, s a következő évek nem várt fordulatot hoztak a debreceni jogászképzés életében, ugyanis „1949 nyarán magasabb

${ }^{28}$ FónAI Mihály, Illyefalvi Vitéz Géza: A statisztikus = A Debreceni Tudományegyetem jogász rektorai, i. $m$., 104 .

${ }^{29}$ A Római jogi szeminárium a II/205-ös helyiségben kapott helyett, majd a második világháborút követően pedig a 203-asba költözött.

A Jogtörténeti szeminárium (kezdetben mint Egyházjog és jogtörténelmi szeminárium) a II/240-es helyiségben talált otthonra, a háború előtt (1939/1940.) pedig az I/139-es helyiségbe szállították át a könyveket.

Az Egyházjogi szeminárium (kezdetben mint Egyházjog és jogtörténelmi szeminárium) központi épület átadása után annak II/240-es helyiségében kapott helyet, majd a háború után a 245-ös helyiségbe szállították át a könyveket.

A Közjogi szeminárium (kezdetben mint egyesített Büntetőjog-közjogi szeminárium) I/139-es, a háború előtt a II/243-as, azt követően pedig a 238-as helyiségben talált helyet magának.

A Politikai szeminárium a II/243-as helyiségben kapott helyet.

A Közigazgatási és pénzügyi jogi szeminárium céljaira a központi épület átadása után annak II/245-ös, a háború után pedig a 239-es helyiségét rendezték be.

A Magánjogi szeminárium (a '20-as években mint Magyar- és osztrák magánjogi szeminárium) a II/203-as, a háborút követően pedig 204-es helyiségben kapott helyet.

A Kereskedelmi- és váltójogi szeminárium a II/208-as helyiségében kapott helyet.

A Perjogi szeminárium a II/208-as helyiségben rendezkedhetett be.

A Közgazdaságtani és statisztikai szeminárium a Ferenc József út 51. szám alól a központi épület átadása után annak II/228-as helyiségébe költözhetett.

A Jogbölcseleti zeminárium (1939-től: Jogbölcseleti és nemzetközi jogi szeminárium) számára az I/141-es, a háború után pedig a 136-os helyiséget rendezték be.

A Büntetőjogi szeminárium (kezdetben mint egyesített Büntetőjog-közjogi szeminárium) is a Ferencz József út 51. szám alatt működött, majd a központi épület átadása után annak I/136-os, a háborút követően pedig a 141-es helyiségébe költözött.

A Kisebbségjogi Intézet a központi épület első emeletén, a 137-es helyiségben működött. Vö. HoLlósı, i. m., 30-178.

${ }^{30}$ Mudrák, Király, i. m., 103. 


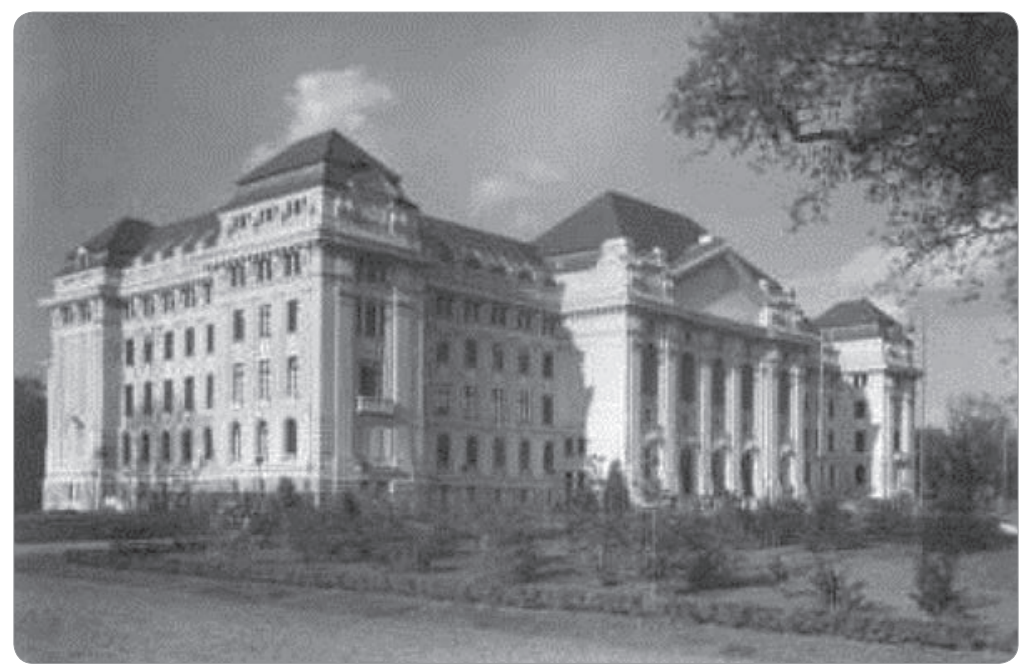

4. kép A Debreceni Magyar Királyi Tudományegyetem központi épülete nem sokkal az átadás után. ${ }^{32}$

kormányzati körökben alig két hónap alatt eldöntetett a debreceni jogi kar "szüneteltetése", tulajdonképpeni megszüntetése" ${ }^{31}$ Mindez azt eredményezte, hogy Debrecen egyetemi épületei évtizedekig nem láttak joghallgatót falaik között.

\section{Az újrakezdés, avagy a Debreceni Egyetem Állam-és Jogtudományi Karának elhelyezése}

A debreceni jogi oktatás 1949-ben bekövetkezett szüneteltetése után , évtizedekre jogászképzés nélkül maradt Debrecen. Visszaállítására több sikertelen kísérletet is tettek, de csak az 1996/1997-es tanévben indulhatott újra. ${ }^{33}$ Az újrakezdés - mint általában

${ }^{31}$ P. SzABó, i. m., 44. A szünetelésről a 4.105/1949. számú kormányrendelet rendelkezett: „2. \$ (2) A Debreceni Tudományegyetem Jog- és Közigazgatás-tudományi Karának működése az 1949. évi augusztus hó 30. napjától kezdve további rendelkezésig szünetel." (A rendelet szövegét közli: HoLlósı, i. m., 274.) A szünetelés gyakorlatilag a kar megszüntetését jelentette, amelyet az is előre jelzett, hogy „....a nyolc, az 1948/1949-i tanévben oktató professzor közül hármat nyugdíjaztak (Bacsó Jenő, Bozóky Ferenc, Szthelo Zoltán), kettőt Pécsre helyeztek át (Flachbart Ernő, Kauser Lipót), hármat pedig Szegedre irányítottak (Dezső Gyula, Vas Tibor, Schultheisz Emil). A már felvett hallgatók évveszteség nélkül beiratkozhattak a három másik jogi kar valamelyikére.” P. SzABó Béla, Hollósı Gábor, A Jog-és Államtudományi Kar = A Debreceni Egyetem története, i. m., 178.

32 Kép forrása: DE ÁJK Hallgatói Önkormányzat Fotóarchívuma.

${ }^{33}$ Már az 1950-es évek végén, illetve majd az 1980-as években került elő ismét a kérdés. (Vö. HolıósI, i. m., 285-288.) „...amikor 1983-ban a kormány a jogászképzés bővítése mellett döntött, ennek haszonélvezője nem a visszaállításra akkor is pályázó debreceni intézmény, hanem a Miskolci Nehézipari Egyetem lett.” (A Debreceni Egyetem története, i. m., 511.) „Az újjászervezés gondolata 1991-ben 
- nehézségekkel járt, amelyek között az elhelyezés kérdése is felmerült. Annál is inkább, hiszen a jogi kar egykori helyiségeit már a szüneteltetés kimondásának pillanatában az ekkor létrejövő önálló Természettudományi Kar részére engedték át. ${ }^{34} \mathrm{Az}$ eltelt évtizedek során a Kossuth Lajos Tudományegyetem belakta, sőt kinőtte az 1932-ben átadott Egyetem téri Fóépületet (amely az eredeti tervekkel ellentétben eleve kisebb méretben valósult meg), így az 1990-es években újonnan induló képzéseknek, így a joginak is helyet kellett találni.

\section{Az újrakezdés helyszine, a Kassai úti laktanya és annak rövid története}

A szovjet hadsereg kivonását követően, az 1990-es évek elején számos ingatlan megüresedett a városban, s szinte nem is volt kérdés, hogy ezek közül lesz olyan, amelyet a felsőoktatásnak adnak át. Ekkor vált szabaddá a nevét visszanyerő Kassai úton az a terület is, amely a 20. század első felében mint huszár-, illetve (az első világháborút követően) tüzérlaktanya volt ismert. ${ }^{35}$ A Kassai úton elhelyezett laktanya 1899 végére épült fel a kor követelményeinek megfelelően pavilonos rendszerben. Ennek köszönhetően a különböző funkciójú épületek elkülönülve álltak a laktanya területén, s körülvették az ún. alakulóteret (Formirungs-Platz), amely a gyakorlatozást szolgálta. A 19. század végén 29 épület fogadta a beköltöző lovasságot, egy 1938-ban készült helyszínrajz viszont összesen $58 \mathrm{db}$, változó rendeltetésủ épületet, illetve épületrészt különböztetett meg. (5. kép)

A lovassági laktanya főbejáratát a Hadházi (ország)útra, a mai Kassai útra nyitották meg, s erre a tengelyre szimmetrikusan helyezkedtek el az épületek jobbra, illetve balra egyaránt. A fötengelyben az ún. törzsépület állt, amelyet korabeli képeslapokon Tiszti kaszinóként is neveztek. (6. kép) Ez az egyemeletes törzsépület a 19. század végi historizáló építészet egyik szép példája.

A Kassai útról a törzsépülethez két kapuépület között vezetett az út, amely körbe ölelve a központi épületet az alakulótér felé vitt. A központi épület jobb-, illetve baloldalán kétemeletes tiszti épületek helyezkedtek el. A baloldali épület (a mai Népegészségügyi Kar székhelye) tiszti, a jobboldali (kancelláriai épület) pedig altiszti lak

a Debreceni Universitas Egyesülés tervébe, 1993-ban pedig az egyetem középtávú fejlesztési tervébe került be." (Szabó Béla, A Debreceni Egyetem Állam-és Jogtudományi Kara = A jogászképzés múltja, jelene és jövője: Ünnepi tanulmányok, konferencia-előadások, kerekasztal-beszélgetések, szerk. TAKÁCs Péter, Budapest, 2003, 289.)

34 Vö. P. SZABó, i. m., 46.

35 A laktanya építészeti kialakításáról jelen tanulmányban csak egy rövid leírás kaphat helyet, a témáról és a terület történetéről lásd bővebben: MegYeri-PÁlfFi, i. $m$. 


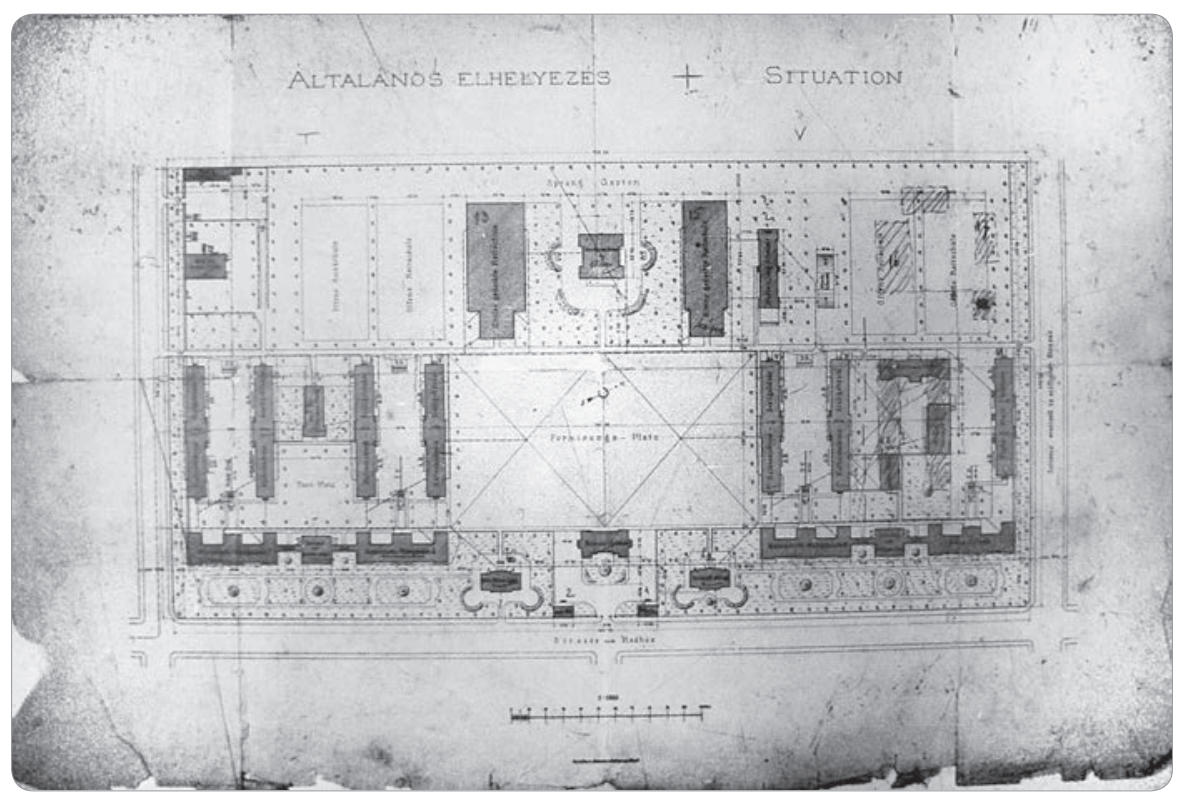

5. kép A debreceni lovassági laktanya általános elhelyezése. ${ }^{36}$

volt. A két épület külső megjelenésben szinte azonos, visszafogottabb díszítést kaptak a törzsépületénél.

A tiszti illetve az altiszti lakoktól távolabb, a Kassai úttal párhuzamosan helyezkedtek el a legénységi épületek, amelyek mind a terület útra merőleges főtengelyére, mind saját tengelyükre szimmetrikusan épültek fel. A legénységi épületek is „ikertestvérek” voltak. Ezek két szállásépületből és az őket összekötő konyhaként és vívóteremként szolgáló épületből álltak.

A legénységi épületek egyemeletesek voltak, középrizalitjuk további emeletet kapott, így hangsúlyos részévé váltak az épületnek. Az ebben az időben épült laktanyák legénységi épületeinél gyakran visszaköszön e forma. Homlokzati struktúrájuk, díszítésük a tiszti lakokhoz hasonló, de valamivel szerényebb volt.

A debreceni huszárlaktanyában az istállókat a legénységi épületek mögött, azokra merőlegesen, fésűszerűen építették fel. Az épületek párhuzamos elhelyezése és az, hogy egymástól magasságuk legalább kétszeres távolságára voltak, biztosította a szellőzésen túl a kedvező benapozást is.

Az alakulótér törzsépülettel átelleni oldalán helyezkedtek el a lovardák. A Vilmos huszár laktanyában két-két nyitott, illetve fedett lovardát építettek. A fedett lovardák között a földszintes markotányos és fürdőépület állt. Ez ma az Egyetem Kancelláriájá-

${ }^{36}$ DMJV Polgármesteri Hivatal Mikrofilmes adattára, Kassai út 26.; é. n., feltehetően az eredeti tervekhez kapcsolt helyszínrajz az 1890-es évekből. 


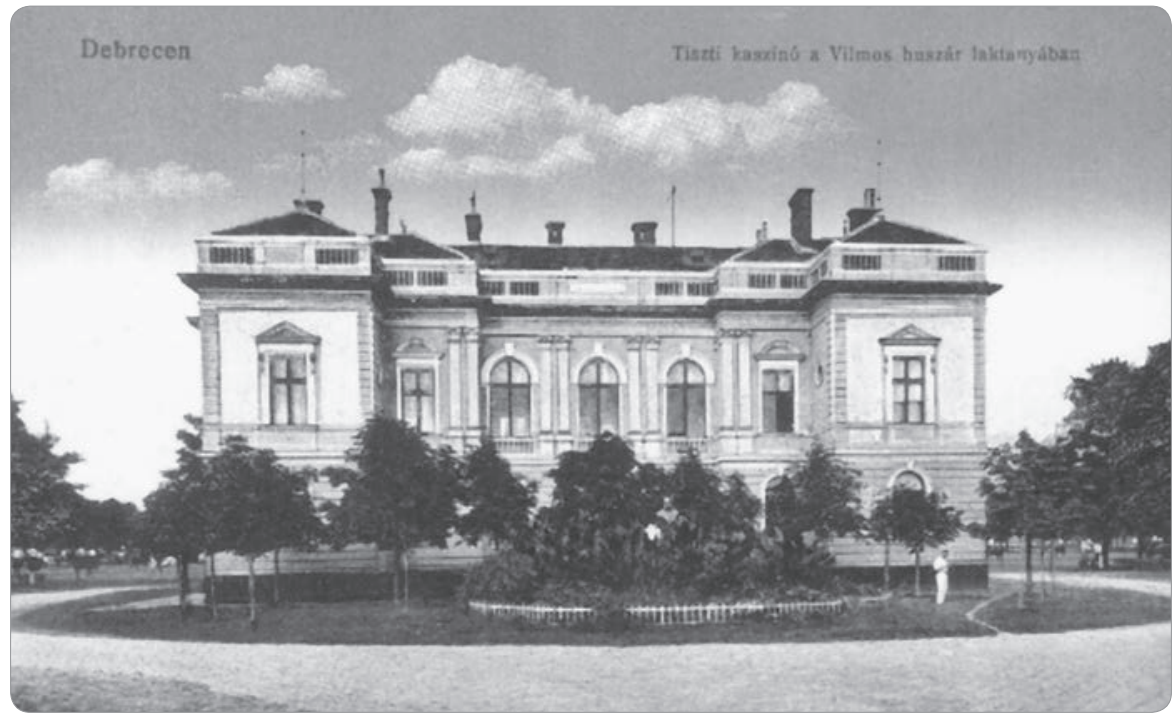

6. kép. Korabeli képeslap: Tiszti kaszinó a Vilmos huszárlaktanyában. A mai Kancellária épülete. ${ }^{38}$

nak III. sz. épülete. A lovardák közül ma már csak a kisebbik fedett lovarda áll, amely 1996-1997-ben Kertai László tervei alapján újult meg. ${ }^{37}$ (7. kép) A felújítást követően Egyetemi Kulturális és Konferenciaközpontként müködik az egykori lovarda. ${ }^{39}$

A laktanyát Debrecen városa építtette, $s$ a közös hadsereg, illetve később a honvédsereg vette tőle bérbe. E jogviszony egészen a második világháború utánig fennállt, majd 1947-ben a város részére visszaadta a honvédség. ${ }^{40}$ Az 1950 -es években már ismét laktanyaként funkcionált a terület, amely Gábor Áronról kapta a nevét. A szovjetek ezekben az években költöztek be a területre. 1957-ben a Laktanya utca és az egykori

${ }^{37}$ Vö. Debrecen Kassai úti Campus területén létesítendő kulturális és szabadidő diákklub építési engedélyezési tervdokumentációja (DMJV Polgármesteri Hivatal Városépítési és Városfejlesztési Osztály Tervtár, Debrecen, Kassai út 26. sz. iratanyaga)

${ }^{38}$ Kép forrása: Hajdú-Bihar Megyei Levéltár honlapja, Képeslapok a régi Debrecenről (http://hbml. archivportal.hu/data/images/kepek/Kep-146.jpg, letöltés ideje: 2012. 03. 27.)

39 Vö. Pilishegyi Péter, Egyetemünk története: A debreceni felsöoktatási integráció nyolc éve 1996-2004, Debrecen, 2005, 60-64. Az épület a jogászok életében is fontossá vált. Az első évfolyamok még itt hallgattak előadásokat, illetve a hátsó traktusban szemináriumok és vizsgák voltak a TEOK megépüléséig. Azóta a kar kulturális rendezvényeinek gyakori helyszíne az épület.

40 A háborút követően, 1947-ben a Kinizsi Tornaegylet bérelte a kis fedett lovardát és a tőle délre fekvő terülteket. Vö. PApp József, Debrecen város birtokkatasztere 1924-1950, A Hajdú-Bihar Megyei Levéltár Közleményei, 23, Debrecen, 1997, 100.; Papp József feljegyzései szerint a 11.408/1949 II. sz. tanácsi határozat említi a területet mint ,ideiglenes használatra, ill. hasznosításra a város részére a H.M. úr 441.400/ elh. 1947. sz. rendeletével visszabocsátva, a város által használva: részben mint szükséglakás, részben raktár, műhely céljára bérbe adva." (DMJV Polgármesteri Hivatal Mikrofilmes adattára) 


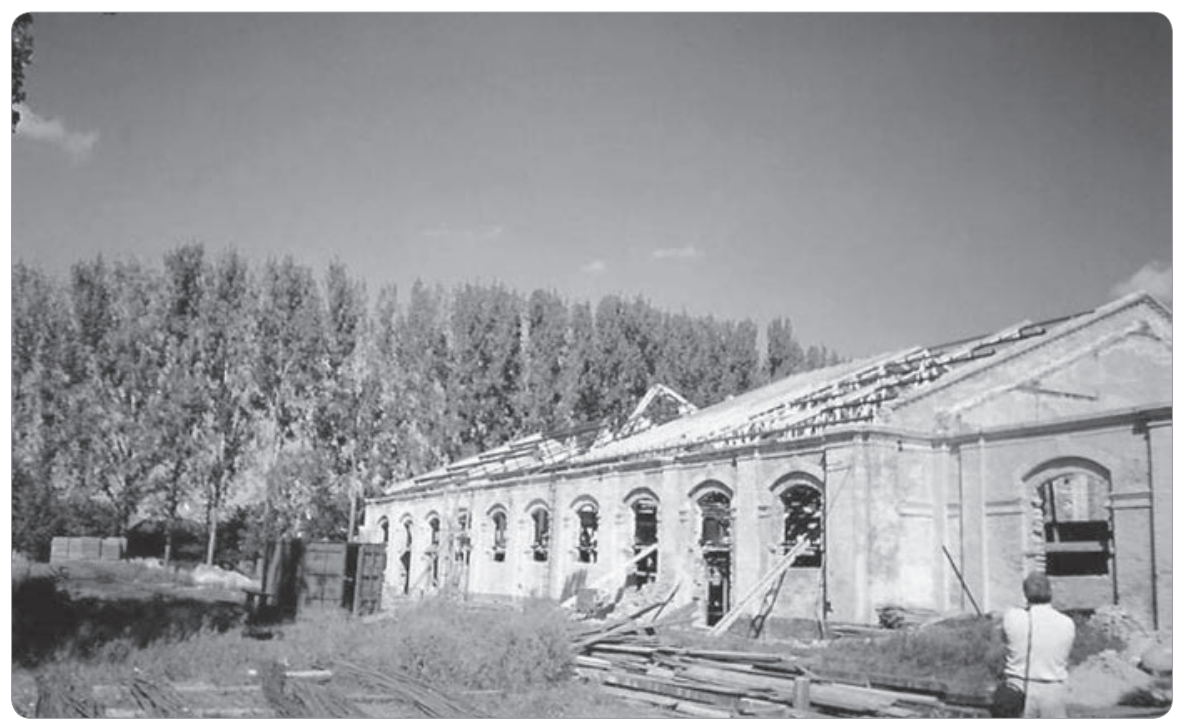

7. kép. A Lovarda a felújitás alatt. ${ }^{41}$

Szabadság útja sarkán elhelyezkedő épületben, a III. kerületi tanács épületében postahivatal és sütőipari helyiségek kialakítására adtak engedélyt. ${ }^{42} \mathrm{~A}$ laktanyának ezt a sarokrészét kerítés választotta el a többitől..$^{43} \mathrm{~A}$ szovjetek az itt tartózkodásuk alatt bővítették a területet, illetve részben a második világháború során elpusztult épületek helyén, részben az egykori istállók és alakulótér területén új épületeket emeltek, összesen 19 darabot. „Az átadás-átvétel során a terület a magyar állam tulajdonába került, az 1990-es évek második felében ugyanakkor a kezelöi jogot a Debreceni Universitas Egyesület kapta meg, amely a debreceni felsöoktatás területi kiterjedésének legfontosabb zálogaként kezelte az ingatlant." 44

A szovjet csapatok kivonulásával megüresedő Kassai úti (akkor még Szabadság útjai) laktanya a debreceni felsőoktatási intézmények integrációjával egy időben, e folyamattal összefüggésben új funkcióval és megújult külsővel nyitotta meg kapuit. A rendszerváltást követően lehetőség nyílt a debreceni felsőoktatási intézmények számára az egyesülésre. 1992-ben létrejött a Debreceni Universitas Egyesülés (DUE), amely sikerrel koordinálta a közös fejlesztések feltételeinek megteremtését és megvalósítását. E célokat jelentősen szolgálta, hogy a megüresedett laktanya kezelését térítésmentesen megkapták. A DUE átvette a területet, amelynek őrzéséről gondoskodott, illetve a közel százéves

${ }^{41}$ Kép forrása: Lovarda Egyetemi Kulturális és Konferenciaközpont honlapja (http://www.lovarda.hu/ galery/1/01_01.jpg, letöltés ideje: 2012.03. 27.)

42 PApr, i. m., 100., illetve vö. DMJV Polgármesteri Hivatal Mikrofilmes adattára, Kassai út 26.

${ }_{3}$ Később ebben az épületben kapott helyet az egyetem Angol Tanárképző Intézete.

${ }^{44}$ KádÁR Kriszta, Kozma Gábor, Az egykori szovjet katonai területek funkcióváltása Debrecenben, Tér és Társadalom 25(2011/2), 170. 
épületek állagmegóvását elvégezte, $s$ megkezdték a megtartásra alkalmatlan volt szovjet és egyéb létesítmények lebontását. ${ }^{45} \mathrm{Az} 1990$-es évtized közepén az egyesült Debreceni Egyetem létrehozása hosszas előkészítés után találkozott a kormányzat szándékaival is, amely a Világbank közreműködését kérte a reformprogram kidolgozásában. A bank 1996 februárjában négy integrációra készülő intézménycsoport (köztük a debreceni) céljainak megvalósításához szükséges Beruházási Program kidolgozását segítette. A forrást a kormány világbanki hitellel kívánta biztosítani. A projektben való sikeres részvétel, illetve a módosuló felsőoktatási törvény rendelkezései miatt, a DUE tagintézményei már 1996 januárjában kinyilvánították szándékukat a Debreceni Egyetemi Szövetség (DESZ) megalapításáról. A DESZ alapprogramjai között szerepelt a Társadalomtudományi és Egészségtudományi Oktatási Központ létrehozása, amelynek a helyét a Kassai úti laktanya területén jelölték ki. A DUE 1996-ban, illetve 1997-ben sikeresen pályázott, és az elnyert 300-300 millió forintból megvalósította fejlesztéseit, amelyek egyike volt a Gábor Áron laktanya központi épületének felújítása a megalakítandó DESZ céljaira. ${ }^{46} \mathrm{~A}$ folyamatos átdolgozáson átesett megállapodások végül 2000 második felében tették lehetővé az új épületek létesítésének előkészítését a területen. Mindennek köszönhetően a következő években tovább folytak a fejlesztések a laktanya területén. ${ }^{47}$ Ezek keretén belül, az időközben újraindult jogi oktatás ${ }^{48}$ helyiséghiányának ${ }^{49}$ orvoslására megindult a laktanya 3. számmal jelzett épületének felújítása. (8. kép)

A tervdokumentációból kiderül, hogy a felújítást jegyző REÁLTERV Kft. már 1994 szeptemberében megkapta az építési engedélyt, de a megépítés megkezdésére csak 1999-ben került sor. Az iroda a korábbi felmérési tervet kiegészítette, a méreteket korrigálta. A felújítással az épület olyan átalakítását végezték el, amely a KLTE Jog- és Államtudományi Intézet tanszékeinek működését tette lehetővé, mindezt úgy, hogy az átépítés a meglévő homlokzati megjelenés értékeit megőrizte. ${ }^{50}$ Az épületet „mint az országos (Világbanki) Felsöoktatási Reform Program elsö (120 millió forint támogatással) megvalósult beruházását 2000. június 30-án adták át ünnepélyes keretek között". ${ }^{51}$

${ }^{45}$ Nagy Sándor, Universitas Egyesülés, Egyetemi Szövetség = A Debreceni Egyetem története, i. m., 466467.

${ }^{46} \mathrm{Ez}$ az egykori törzsépület. A felújított épületet 1998. március 27-én avatta fel Magyar Bálint művelődési és közoktatási miniszter. Pilishegyi, i. m., 30.

47 Vö. uo. 466-469.

${ }^{48}$ A jogi oktatás újraindításáról lásd: SzABó, i. $m$.

49 A helyiséggondokra jellemző, hogy az 1996. évi indulást követő esztendőkben amellett, hogy a tanulmányi adminisztráció a bölcsészkaron működött, a tanszéki és előadói helyiségek a Közgazdaságtudományi Kar épületében voltak.

${ }^{50}$ Vö. KLTE Jog- és Államtudományi Intézet építési engedélyezési tervdokumentáció, Debrecen, Kassai út 26., Építész tervező: Kálmán Ernő, REÂLTERV Építőipari Tervező, Fővállalkozó, Ingatlanközvetítő és Építőanyag Értékesítő KFT. (DMJV Polgármesteri Hivatal Városépítési és Városfejlesztési Osztály Tervtár, Debrecen, Kassai út 26. sz. iratanyaga)

${ }^{51}$ NAGY Sándor, Universitas Egyesülés..., i. m., 470. 


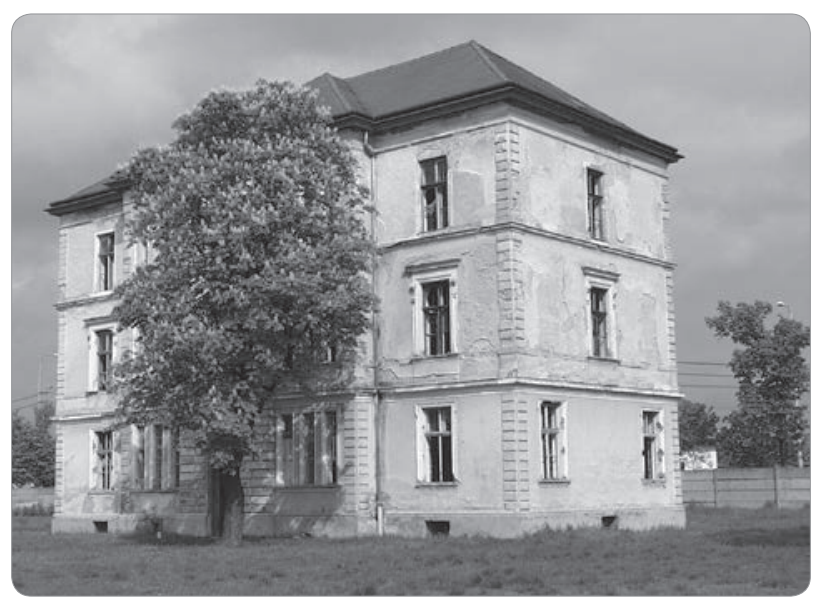

8. kép. A laktanya 3. számú épülete, a DE ÁJK késöbbi széképülete a felújitás elött. ${ }^{52}$

A következő évek fejlesztései a jogászoktatás infrastrukturális alapjait tovább erősítették. Erre szükség volt, hiszen a tanszéki épület átadása az intézet oktatási tevékenysége terén a helyhiányt nem számolta még fel. Ezekben a tanévekben a hallgatók nemcsak a laktanya már kész épületeiben (Közgazdaságtudományi Kar épületei, Lovarda), hanem város más részein elhelyezkedő egyetemi épületekben is hallgattak jogi órákat. Egy-egy oktatási napon ezek az évfolyamok az egyetem Főépületének Aulájában, a Kölcsey Ferenc Református Tanítóképző Főiskola, valamint a Müszaki Főiskola épületében is megfordultak. 2002-ben a Társadalomtudományi és Egészségtudományi Oktatási és Központ és Könyvtár ${ }^{53}$ (TEOK) megépítésével sikerült ezeket a nehézségeket is felszámolni. Az épület több ütemben valósult meg. Elsőként a szemináriumi termeket és nagyelőadókat is magában foglaló oktatási szárny, majd a Társadalomtudományi Könyvtár épült fel, mely utóbbiban a jogi és közgazdaságtudományi szakirodalom kapott helyet. ${ }^{54}$

Az Állam- és Jogtudományi Kart érintő fontos fejlesztés volt a campuson található, az egykori III. kerületi tanácsnak, majd az Egyetem Angol Tanárképző Intézetének otthont adó épület felújítása. Ez orvosolta azt a helyhiányt, amely a 2000-ben átadott tanszéki épület időközben bekövetkezett kinövéséből adódott. A kar néhány tanszékével már a felújítás előtt belakta az épület egyes részeit, azonban a végső megoldást a teljes felújítás után találták meg. Az épület mint inkubátorház (TEK Kreatív Iparágak Inku-

${ }^{52}$ Kép forrása: DE ÁJK Hallgatói Önkormányzat Fotóarchívuma.

53 Építész tervező: Kálmán Ernő és Major György, REÁLTERV Építésziroda Kft. (Építési engedélyezési tervdokumentáció, Debreceni Egyetem - Társadalomtudományi és Egészségtudományi Oktatási Központ, Debrecen, Kassai út 26., DMJV Polgármesteri Hivatal Városépítési és Városfejlesztési Osztály Tervtár, Debrecen, Kassai út 26. sz. iratanyaga)

54 Vö. Virágos Márta , Az Egyetemi Könyvtár = A Debreceni Egyetem története, i. m., 398. 
bációs Központja ${ }^{55}$ ) a jogi kar négy tanszékén kívül informatikai cégek irodáinak adott helyet egészen 2015-ig, amikor ismét új helyre költözött a kar. Ez a legutóbbi változás a gazdaságtudományi karok integrációjával függött össze. ${ }^{56} \mathrm{~A}$ korábbi Közgazdaság- és Gazdaságtudományi Kar (KTK) épületegyüttesét (az épen maradt, a főbejárattól jobbra eső egykori legénységi épületet) az Állam- és Jogtudományi Kar kapta meg. (9. kép)

Az átköltözés lehetősége már 2014 során felmerült, amikor is, április 8-án az elökészületek megbeszélése miatt összegyültek, és helyszíni bejárást tartottak a jogi kar, a Műszaki- és Üzemeltetési Főosztály és a Műszaki Osztály képviselői. Ezen bejárás célja az épület megismerése és általános müszaki állapotának felmérése volt. Majd a nyári hónapok folyamán a KTK kiköltözött az épületből, s megkezdődhettek a felújítási munkálatok, amelyek finanszírozásában a kar és az egyetem mellett a Hallgatói Önkormányzat is részt vett. ${ }^{57}$

A felújítás után végül a jogi kar átköltöztetése két ütemben történt meg. Elsőként a kari „f”épületbő”" (mai Kancellária II. sz. épület) költözött át az A és B egységekbe. A második ütemben, 2015. február végén, a $C$ épületrészben elkészült irodákat foglalhatták el azok a jogi kari tanszékek, amelyek korábban az inkubátorházban működtek. ${ }^{58}$ Végül az ünnepélyes átadásra 2015. május 22-én került sor. A jogi kar korábban a campus területén található két másik épületben működött, ezekbe a Kancellária egységei kerültek utóbb.

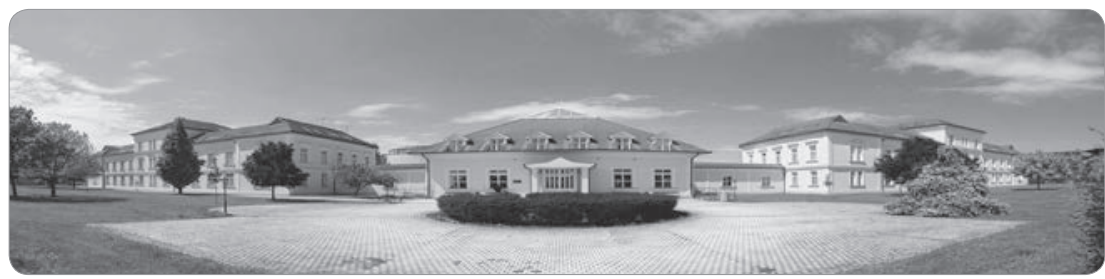

9. kép. A Debreceni Egyetem Állam-és Jogtudományi Karának jelenlegi épülete a Kassai úti Campuson. ${ }^{59}$

55 Az épületet 2010. február 19-én nyitották meg. (TEK Hirlevelek, II. évf. 2. sz. „Megnyílt a Debreceni Egyetem Kreatív Iparágak Inkubációs Központja” http://www.unideb.hu/portal/hu/node/2987, letöltés ideje: 2012. 03. 27.) A felújítás terveit id. Kálmán Ernő jegyezte (REÁLTERV Kft.), a kivitelezést az ÉPKERSERVICE Építőipari Kereskedelmi és Szolgáltató Zrt. végezte. Vö. Egyetem és épitészet: A Debreceni Egyetem jelentösebb beruházásai 2000-2012, szerk. BonbéLY Tamás, Debrecen, 2012, 54.

${ }^{56}$ A 2013/2014-es tanév során folyt le a Debreceni Egyetem gazdaságtudományi képzéseinek integrációja, amelynek eredményeként 2014. augusztus 1-jétől Gazdaságtudományi Kar néven folytatja működését a korábbi Közgazdaság- és Gazdaságtudományi, valamint a Gazdálkodástudományi és Vidékfejlesztési Kar. Vö. Szilvássy Zoltán, Rektori bevezetö = Debreceni Egyetem Évkönyve (2013. július 1.-2014. június 30.), szerk. Rőfi Mónika, Rózsa Judit, Debrecen, 2014, 7.

57 Vö. Debreceni Egyetem Évkönyve (2014. július 1.-2015. június 30.), szerk. Rőfi Mónika, Szabóné Rózsa Judit, Debrecen, 2014, 230.; valamint Szabadfalvi József dékán 2014. 07. 02-án kelt kari tájékoztató levele alapján.

58 Szabadfalvi József dékán 2015. 02. 04-én és 11-én kelt kari tájékoztató levele alapján.

59 A kép forrása a Debreceni Egyetem Állam- és Jogtudományi Kar honlapja, https://jog.unideb.hu/ sites/default/files/panorama_slider.jpg (letöltés ideje: 2017. 11. 07.) 


\section{Zárszó}

A jogi oktatás mind az induláskor, mind az újrakezdéskor kereste helyszínét. Míg az induláskor valamennyi egyetemet alapító kar várta az elhelyezést, addig az újrainduláskor csak ezt az intézményt érintette a probléma, de megoldásában nem maradt segítő kezek nélkül. Összességében mégis kísértetiesen hasonló a két korszak problémája. A Főépület átadásáig is az ideiglenesség és a várakozás hatotta át a jogászképzést, csakúgy, mint abban a néhány évben, míg az elhelyezés gondjai meg nem oldódtak az újraindulás után. Azok a hallgatók, akik még részesei voltak a napközbeni vándorlásnak, ma már mosolyogva emlékeznek vissza arra, hogy jogászok hada lepte el a huszonnégyes buszt, hogy az akkori Tanítóképzőn (Péterfia utca 1-7.) tartott egyetemes jogtörténet elöadásról időben átérjenek a Lovarda néha kicsit sörszagú miliőjébe római jogot hallgatni.

A TEOK felépültével mindez már csak emlékké vált. Persze újabb emlékek az újabb helyekhez is kötődnek, hiszen ki feledné a kék linóleum sajátos varázsát vagy, hogy hogyan zenél az új épület nyári zápor idején.

A város azon területe, amely a mai campusnak ad otthont, a fiatalok nyüzsgö, de mégis valamilyen értelemben rendezett életének ad, adott teret. Érdekes, hogy e hely megőrizte eredeti jellegét, hiszen laktanyaként is sokak életének meghatározó terévé vált, csakúgy mint egyetemi campusként. A funkcióváltás óta eltelt húsz év alatt a beruházások nemcsak az egyetemi oktatás közvetlen céljait szolgálták, hanem igazi kampusszá tették az egykori laktanyát. Az egyetem hallgatói mellett a város fiataljainak kulturált szórakozását szolgálja a Lovarda. Az állandó nyüzsgő életet biztosítja a Campus Hotel. S újabb rendezett zöldfelület született a Zöld Hullám Park megépítésével, amely az egykori alakulótér utódjaként, de már kényelmes és nyugodt kikapcsolódásra invitálja az erre járókat.

Arról se feledkezzünk meg, hogy a campus újabb kart fogadott be, az Informatikai Kart, valamint itt épült fel két jellegzetes „kocka-épület”, a Műszaki Kar számára épült az ún. Fenntartható Épületenergetikai Demonstrációs Központ (DEM) Ferencz Marcel tervei alapján (2013), és az ugyancsak általa, valamint Détári György által tervezett, LEÓ névre keresztelt Szuperszámítógép Központ (2015).

Mára joggal mondhatjuk, hogy másokkal együtt a jogászok „hadiszállásává” vált az egykori laktanya, ahol jól megfér egymással a múlt és a jelen, s nevelődnek a jövő generációi. 